\title{
European Cultural Protectionism AND THE SOCIOECONOMIC FORCES THAT WILL DEFEAT IT
}

\section{INTRODUCTION}

The last minute concession was forced upon President Clinton in the early morning hours of December 14, 1993. The European trade delegation would not compromise on the issue of audiovisual trade. The debate over the "cultural exclusion" for trade protections of entertainment products would have to be tabled, so that negotiations on the Uruguay Round Trade Accord ${ }^{1}$ to the General Agreement on Tariffs and Trade (GATT) ${ }^{2}$ could proceed. Some U.S. officials continued to assert that the "cultural exclusion" was superseded by the GATT agreement. ${ }^{3}$ But in March of 1994, the U.S. ambassador to the European Union (EU), Stuart Eizenstat, said that the United States would not pursue sanctions in the dispute. ${ }^{4}$ And so, with an oddly appropriate

1. On December 15, 1993, participants from 117 countries concluded the Uruguay Round of international trade negotiations to expand and revise the 45 year old GATT treaty regulating worldwide trade. The Uruguay Round Trade Accord, a document over 400 pages in length, is the result of seven years of negotiations that began in Punta del Este, Uruguay, in Sept. 1986. The Accord must be ratified by each participating nation before taking effect. If ratification proceeds as expected, the Accord should become effective July 1, 1995. Lisa B. Martin and Susan L. Amster, International Intellectual Property Protections in the New GATT Accord, 6 J. PROPRIETARY RTS. 9 (Feb. 1994). See also Final Act Embodying the Results of the Uruguay Round of Multilateral Trade Negotiations, opened for signature Dec. 15, 1993, Doc. No. MTN/FA II-AIC [hereinafter Uruguay Round Accord].

2. The General Agreement on Tariffs and Trade, opened for signature Oct. 30, 1947, 61 Stat. A3, 55 U.N.T.S. 187 [hereinafter GATT] creates international obligations among its members concerning the trade of goods. The primary goal of GATT is to ensure national treatment of imported goods by the importing country, and to ensure common levels of tariffs for all signatory members of GATT for intra-GATT trade. See Stacie I. Strong, Banning the Cultural Exclusion: Free Trade and Copyright Goods, 4 DUKE J. CoMP. \& INT'L L. 93, 103 (1993). Common levels of tariffs are based on the most favored nation principle, which requires a member state to apply the lowest tariff rate set by it to all other member states. Id.

3. One argument put forth was that, because the GATT General Agreement on Trade in Services (GATS) text contains no explicit provision for excluding broadcasting services, they are still covered by the GATS agreement. GATT Deal Is Signed but Row Continues, SCREEN FIN., Apr. 20, 1994, available in WESTLAW, INT-NEWS-C Database. See also General Agreement on Trade in Services, Dec. 15. 1993, 33 I.L.M. 44. Note that broadcasting has been held to be a service rather than "goods" within the meaning of the GATT treaty, and is therefore not eligible for basic GATT protections. Michael Braun \& Leigh Parker, Trade in Culture: Consumable Praduct or Cherished Articulation of a Nation's Soul?, 22 DENV. J. INT'L L. \& POL'Y 155, 179 (1993). See also GATT, supra note 2, Introduction.

4. GATT Deal Is Signed but Row Continues, supra note 3. The U.S. could retaliate through "Super 301" sanctions, which include trade tariffs and quotas. Omnibus Trade and Competitiveness Act of $1988 \S 301,19$ U.S.C. $\$ 2411$ (a) (1994). See also Lisa L. Garrett, Comment, Commerce Versus Culture: The Battle Between the United States and the European Union over Audiovisual 
air of drama, the fiction of "cultural" versus "commercial" products was temporarily sustained. ${ }^{5}$

The refusal to deal on "cultural exemptions" has succeeded in preserving the existing system of audiovisual quotas and subsidies from GATT antiprotectionist measures. ${ }^{6}$ This gives the European audiovisual industry a brief respite in which to reverse its downward slide. According to the European Commission (EC), the EU's audiovisual market is worth 257 billion Ecus (325 billion U.S. dollars). ${ }^{7}$ In the past ten years, European films have lost fifty percent of the European cinema screens and two thirds of the audience. ${ }^{8}$ Only twenty percent of European films get distribution outside their country of origin, and almost none achieve the box office success of their Hollywood counterparts. ${ }^{9}$ Although EC officials have disclaimed any anti-U.S. motivation behind audiovisual protectionist measures, it is clear that American domination of the audiovisual market is the primary target. ${ }^{10}$ Europe accounts for sixty percent of the United States' audiovisual exports, and the total has increased

Trade Policies, 19 N.C. J. INT'L L. \& COM. REG. 553, 574 (1994).

5. Article 36 of the Treaty of Rome allows materials of cultural significance to be exempted from Treaty provisions regulating trade. Treaty Establishing the European Economic Community EEC Treaty, Mar. 25, 1957, art. 36, 298 U.N.T.S. 11. Although copyrighted goods and services now fall within GATT protections, GATT permits states to exclude certain items from GATT because of their "artistic value" to a state's culture. GATT, supra note 2 , art. XX(f). GATT also contains provisions to allow cinema quota restrictions on foreign films. Id. art. IV. These quota restrictions were included in the original 1947 treaty to aid the flagging European post-war film industry. See Braun \& Parker, supra note 3, at 182 (discussing this and other GATT provisions which may be relied upon to support audiovisual quotas). The Article IV quota provision may be the clearest proof of an intended difference in GATT of treatment between commercial and cultural trade. Id. at 183.

6. 'Vague' Green Paper Must Be Reworked, SATELLTTE TV FIN., Mar. 30, 1994, available on LEXIS, News Library, CURNWS File.

7. Brussel's TV on the Blink, ECONOMIST, Nov. 12, 1994, available in WESTLAW, INT-NEWS-C Database.

8. Sarah Lambert, Europe Wants Action to Save its Film Industry, THE INDEPENDENT, Apr. 8, 1994, at 10.

9. Audiovisual Production: A Strategy to Create Jobs and European Culture, MultinAtional SERVICE, Apr. 12, 1994, available on LEXIS, News Library, CURNWS File.

10. "We are definitely not engaged in a crusade against the United States," EU audiovisual minister Joao de Deus Pinheiro has stated emphatically. Euros Reassures U.S.; A/V Minister Says Cooperation is the Answer, DALY VARIETY, June 21, 1994, NEWS section, at 1. However, a European speaker at the Apr. 1994 "Media in Europe Toward the Millennium" conference in Brussels sums it up differently: "Let there be no mistake. We mean American films and American programming." Joe Cappo, Europeans See U.S. as Threat to Their 'Highway' Conference, ADVERTISING AGE, Apr. 11, 1994, available in LEXIS, News Library, CURNWS File. 
from 330 million Ecus in 1984 to 3.6 billion Ecus in 1992." That leaves the EU with an audiovisual deficit of around 3.5 billion Ecus a year. ${ }^{12}$ In cinema alone, the U.S. share of European screens has risen over the past fifteen years from thirty-five to eighty percent. In contrast, Europe's film industry claims only one percent of the American market. ${ }^{13}$ The United States also has significant leverage in broadcast programming. MTV Music Television is the number one station among young European viewers. ${ }^{14}$ Ted Turner's Cable News Network is the leading news operation. ${ }^{15}$

Beyond the economic concern lies the fear that American Culture will inundate and destroy the indigenous cultures of Europe. "Europeans must avoid Europe's becoming an advance outpost of American civilization," warned Leon Schwartenberg, president of the Intergroupe Cinema of the European Parliament. ${ }^{16}$ Lobbying French filmmakers adopted the epithet, "transforming the grandchildren of Moliere into the grandchildren of Coca-Cola," to dramatize this issue. ${ }^{17}$ Many in the American industry hold the French responsible as the driving force behind protectionism in the European film industry. ${ }^{18}$ The French alone, however, did not preserve the EU subsidy and quota system that December in Geneva.

Collateral questions have been raised as to the effect of violent American programs on European society. The relentless brutality in American entertainment is generally perceived to be a reflection of the American lifestyle. ${ }^{19}$ The inevitable question is whether, by receiving such violent programming, Europeans will be indoctrinated with a greater indifference to suffering, or worse, a penchant for violence. ${ }^{20}$ A shocking killing spree in October 1994 by a young French couple, apparently inspired by the movie "Natural Born Killers," punctuates the reasonableness of such concern. ${ }^{21}$ At least one European country has postponed the release of the 1994 Oliver

11. Brussel's TV on the Blink, supra note 7.

12. Id.

13. Id.

14. Cappo, supra note 10.

15. Id.

16. Fred Hift, Europe 's New Tactic in Media War, CHRISTIAN SCIENCE MONITOR, Aug. 16, 1994, at 13.

17. Cappo, supra note 10.

18. Ian Griffiths, Starring Role Awaits British Film Moguls, EVENING STANDARD, Sept. 26, 1994, at 40 . C4.

19. Sharon Waxman, Paris Reels from Cinema Verite, WASH. POST, Oct. 8, 1994, at

20. Id.

21. Id. 
Stone film because of apprehension over copycat murders in France and the United States. ${ }^{22}$

This note does not attempt to grapple with the moral and ethical questions posed by the merging and evolution of cultures. Rather, it makes an in-depth examination of the future direction of European audiovisual legislation, and the socioeconomic forces which will be encountered. The analysis begins in Part II with an overview of present laws regarding broadcast content quotas and production subsidies. Part III is devoted to recent proposals for changes in European audiovisual legislation. The focus then turns in Part IV to the economic and social environment which the industry is likely to encounter, and how proposed legislation will function in that environment. Part V suggests a course of action that would allow the European audiovisual industry to meet short-term programming needs while growing into a world-class entertainment production entity.

\section{EUROPE'S PRESENT AUDIOVISUAL QUOTA AND SUBSIDY SYSTEM}

\section{A. Broadcast Quotas}

EU broadcast quotas are derived primarily from the 1989 "Television Without Frontiers" Directive (TWFD). ${ }^{23}$ The TWFD was implemented in response to European production weakness and American dominance of the broadcast market. Article 4 contains the language of the cultural quota, requiring that European broadcasters devote a preponderance of their broadcast time to "European Works," as defined by Article 6 of the TWFD. ${ }^{24}$

22. Dan Conaghan, Film Blamed for Murders Held Up by Censors, DAILY TELEGRAPH, Oct. 28, 1994, at 4 .

23. Council Directive of $89 / 552$ of 3 Oct. 1989 on the Coordination of Certain Provisions Laid Down By Law, Regulation, or Administrative Action in Member States Concerning the Pursuit of Television Broadcast Activities, 1989 O.J. (L 298) 28 (hereinafter TWFD). The provisions of the TWFD are almost identical to those included in the Council of Europe Convention on Transfrontier Broadcasting, drafted six months before the TWFD. See European Convention on Transfrontier Broadcasting, Mar. 15, 1989, Europ.T.S. No. 132, art. 10. The Council of Europe has 32 members, including the $12 \mathrm{EC}$ Member States and 20 other European countries. CoOpers \& LyBRAND, E.C. COMMENTARIES, Audiovisual COMMUNICATIONS, $\S 4$ (Sept. 22, 1994) [hereinafter CoOPERS \& LYBRAND].

24. TWFD, supra note 23 , art. 4 provides that:

Member States shall ensure where practicable and by appropriate means, that broadcasters reserve for European works, within the meaning of Article 6(a), a majority proportion of their transmission time, excluding the time appointed to news, sports events, games, advertising and teletext services. This proportion, having regard to the broadcaster's informational, educational, cultural and entertainment responsibilities to its viewing 
The Article 4 language contains several relative terms that allow diverse EU Member State interpretations, and, in some cases, even avoidance. Some flexibility was intentional to allow Member States to incorporate the policies of the TWFD into their own national laws, as per Article 3 of the directive. ${ }^{25}$ Most Member States have legislation implementing the TWFD quotas. ${ }^{26}$ However, charges from European audiovisual lobbies of systematic evasion of the quota restrictions in some Member States have made the flexible language of Article 4 a major point of contention. ${ }^{27}$

The EC has informed Member States that in 1994 it intends to begin utilizing the review and enforcement provisions of the Maastricht Treaty to insure compliance with EC rules. ${ }^{28}$ Article 169 creates a three-step review process of potential infractions. ${ }^{29}$ In the first stage, the EC corresponds with the Member State about the issue in question. The EC may then drop the inquiry, or move to the second stage and deliver a "Reasoned Opinion" to the Member State. ${ }^{30}$ The Reasoned Opinion sets out a course of action for compliance with EU legislation, and gives the Member State a deadline to act. ${ }^{31}$ The third step is to initiate proceedings in the European Court of Justice. $^{32}$ In 1994, the EC resolved to instigate court proceedings against the United Kingdom (U.K.) for licensing foreign satellite stations to broadcast without obligating them to meet TWFD quotas. ${ }^{33}$

In the interest of preserving lucrative satellite movie channels, the British Department of National Heritage (DNH) has opposed the legality of mandatory

Id.

public, should be achieved progressively, on the basis of suitable criteria.

25. Laurence G. C. Kaplan, The European Community 's "TelevisionWithout Frontiers" Directive:Stimulating Europe to Regulate Culture, 8 EMORY INT'L L. REV. 255, 289 (1994). Critics point to several specific TWFD phrases as being overly broad. "[W]here practicable" has allowed an unlimited number of excuses to implementation of the TWFD quotas. "[A]ppropriate means" permits a wide range of legislative strategies, without entailing any specific mode or prohibiting any specific course of action. Similarly, the admonition to "progressively" achieve a majority proportion "on the basis of suitable criteria" provides no clear working guidelines. See id. at 288. See also Brussel's TV on the Blink, supra note 7.

26. See Kaplan, supra note 25 , at 295 - 301, for a thorough discussion of individual EC Member State legislation implementing the TWFD broadcast quotas.

27. See Brussel's TV on the Blink, supra note 7.

28. New Weapon in European Community Compliance Battle, Bus. EuR., Aug. 15, 1994, available in LEXIS, News Library, CURNWS File.

29. See Maastricht Treaty on Political Union, Feb. 7 1992, 31 I.L.M. 247, art. 169 [hereinafter Maastricht Treaty].

30. New Weapon in European Community Compliance Battle, supra note 28.

31. Id.

32. Italy Taken to Court Over TV Directive, TECH EUROPE, Sept. 6, 1994, available in LEXIS, NEWS Library, CURNWS File.

33. Id. 
broadcast quotas. ${ }^{34}$ The U.K. and the EC audiovisual commission Directorate General X (DG-X) disagree about how countries gain jurisdiction over satellite broadcasts for quota purposes. DG-X officials suggest that the DNH has been "deliberately misleading" over the TWFD's meaning of jurisdiction. ${ }^{35}$ The commission claims that laws such as those regarding the place of establishment of fishing boats would control. ${ }^{36}$ Article 171 of the Maastricht Treaty will allow the EC to fine the U.K. if it refuses to comply with the pending ruling of the Court of Justice. ${ }^{37}$

An audit of the efficacy of TWFD quotas shows that most land-based European stations have met or exceeded the fifty-one percent standard. ${ }^{38}$ The highest levels remain with publicly owned channels (which constituted almost all networks until the late 1980 's). ${ }^{39}$ Commercial channels, which usually relied on low-priced American fare when starting out, are also falling into line. ${ }^{40}$ However, there's still some question whether TWFD quotas can be credited with creating these levels, as the survey was held during the years of 1991 and 1992, before most national legislation became fully binding. ${ }^{41}$

\section{B. Cinema Quotas}

The 1947 GATT treaty allows nations to set legislative limitations on the number of foreign films shown in domestic cinemas. ${ }^{42}$. There are currently no EC-wide quotas on the number of domestic films shown in European cinemas. ${ }^{43}$ However, individual Member States may create national quotas and quota-like restrictions.

34. Lambert, supra note 8, at 10.

35. Brussels Considers Quota Deal as UK Row Looms, SCREEN FIN., June 1, 1994, available in WESTLAW, INT-NEWS-C Database. The DG-X argues that the TWFD defines the licensing country as the one where a television channel is "established." Id. UK officials contend that it is licensed where it maintains the satellite uplinks or transponder frequencies. Id. The DG-X rejects the UK's position because of the extreme mobility of satellite uplinks, which may be mounted on trucks. Id.

36. Id.

37. New Weapon in European Community Compliance Battle, supra note 28.

38. Peter Goodwin, Air Traffic Controls-EuropeanProgramming, BROADCAST, May 13,1994 , at 16.

39. Id.

40. Id.

41. Id.

42. GATT, supra note 2, art. IV.

43. Diana Quintero, American Television and Cinema in France and Europe, 18 FLETCHER F. WORLD AFF. 115 (Summer/Fall 1994), available in WESTLAW, TP-ALL Database. 
In some Member States, cinema restrictions are financial in nature. A 1994 change in Italian law replaces the previous obligatory cinema quota regime with a program of tax breaks for movie houses screening indigenous product. ${ }^{44}$ France implements a levy system, requiring film producers to pay an average of eleven percent of cinema box office receipts into a fund to finance and publicize French films. ${ }^{45}$ The system effectively functions as a discriminatory tariff, because French legislation and government regulations make it almost impossible for non-EC producers to qualify for funding from the levy. ${ }^{46}$

Spain has a more traditional cinema quota system. In towns of 125,000 residents or more, Spanish law demands that every two days dedicated to American films must be followed by one day of European movies. ${ }^{47}$ In smaller towns, theaters must show one day of European movies for every three days of American films. ${ }^{48}$

Additionally, Spain requires distributors to first release an EU or Spanish film before allowing domestic access to the distributor's foreign film. ${ }^{49}$ The Spanish government controls market access through "dubbing licenses." ${ }^{50}$ Without a dubbing license, the distributor must release the film without dubbing, which renders a foreign movie practically unmarketable in Spain. ${ }^{51}$ The number of dubbing licenses granted depends on the success of the Spanish or EU films previously released by the distributor. ${ }^{52}$ U.S. officials claim that the dubbing laws allow only fifty American films to be screened each year, given the numbers of Spanish and EU films normally released in Spain. ${ }^{53}$

The United States has already raised the issue with the Organization for Economic Co-operation and Development (OECD), and intends to continue pushing for the elimination of the system. ${ }^{54}$ Spanish distributors recently won a ruling from the Directorate-General IV (DG-IV) (which is responsible

44. GATT Deal is Signed but Row Continues, supra note 3.

45. Margaret Moore, International Film Co-production Tax and Subsidy Mechanisms, 16 HASTINGS COMM/ENT. L.J. 287, 296 (1994), available in WESTLAW, TP-ALL Database.

46. See id. See also Anne Moebes, Structuring Media Joint Ventures in the European Community, 14 HASTINGS COMM/ENT. L.J. 1, 10 (1991).

47. Kaplan, supra note 25 , at 302.

48. Id.

49. Id. See also Rick Setlowe, U.S. Pic Makers Seek Ways, Coin to Gu Int 'l, DallY VARIETY, July 20, 1994, available in LEXIS, News Library, CURNWS File.

50. Id.

51. Id.

52. Id. Mark Damon, president of the distribution company MDP Worldwide, explains that "' [i]f a Spanish or European Common Market film does, say, 20 million pesetas [about $\$ 143,000$ U.S. dollars], it gets one license for the distributor; 40 million gets two ..." Id.

53. GATT Deal Is Signed but Row Continues, supra note 3.

54. Id. 
for EC competition issues), holding that part of the dubbing license system violates the Treaty of Rome. ${ }^{55}$

\section{Audiovisual Subsidies}

Subsidies are a fundamental part of the European audiovisual system. Large government-controlled support programs for the audiovisual sector have been established at both the EC and Member State levels. Money is generally available for all areas of production, including scripting and development, production, editing, prints, distribution and promotion of films.

\section{National Subsidies}

Sixty-five percent of European films in production during the summer of 1994 received some kind of Member State subsidy. ${ }^{56}$ In some cases, the subsidy is relatively small, but may still act to stimulate additional investment. ${ }^{57}$ The percentage subsidy breakdown by nation during the summer of 1994 is:

\begin{tabular}{lcc} 
NATION & FILMS & SUBSIDIZED \\
\cline { 2 - 2 } Denmark & 10 & $90 \%$ \\
Belgium & 8 & $88 \%$ \\
Switzerland & 12 & $83 \%$ \\
Germany & 60 & $83 \%$ \\
Netherlands & 20 & $80 \%$ \\
Sweden & 9 & $78 \%$ \\
France & 91 & $59 \%$ \\
United Kingdom & 55 & $40 \%$ \\
Italy & 56 & $39 \%$
\end{tabular}

Additionally, fifty-one percent of European films received television backing during the summer of $1994 .{ }^{59}$ This is often regarded as a quasisubsidy, because of government ownership or control of broadcaster production

55. Id. See also Treaty of Rome, supra note 5. Article 36 regulates anti-competitive Member State laws.

56. European Features: 510 in Production, Another 2,271 in Development, SCREEN FIN., July 27, 1994, available in LEXIS, News Library, CURNWS File [hereinafter European Features]. Subsidy awards in most countries favor culture over commercial appeal, but a counter trend is appearing. Id. Several countries are merging co-controlling agencies to create a standardized national criteria for awards. Id.

57. Id.

58. Id.

59. Id. Smaller countries like Belgium and Switzerland may have nearly one hundred percent television backing of domestic film production. Id. 
investments. ${ }^{60}$ France had television backing for seventy-four percent of its films, Germany had sixty-three percent, and the U.K. had forty-four percent television backing. ${ }^{61}$

In France, nearly one percent of the national budget is allocated to culture, amounting to 13.5 billion francs in 1994 (about 2.5 billion U.S. dollars) ${ }^{62}$ There are at least six sources of grants for the French movie industry, all of which receive money from the government. ${ }^{63}$ Money is channeled into film subsidies from levies on cassette rentals, cinema tickets, and privately owned television programmers. ${ }^{64}$ About half the money collected from levies goes to buying new films, usually on the strength of the script. ${ }^{65}$ The rest goes to the government's general filmmaking fund, script-writing fund, pre-production fund, production fund, cinema owners' fund, and film distributors' fund. ${ }^{66}$

In 1994, the French Television producers' organization, USPA, formed a collective body to promote French television production internationally. ${ }^{67}$ The confederation is likened to support systems already in place for French cinema production. ${ }^{68}$ The French government will sponsor USPA with a budget in 1995 of 25 million francs (approximately 3.1 million U.S. dollars).

The U.K. eliminated its largest subsidy program, the Eady Levy, in the 1985 Films Act. $^{69}$ The French-style revenue-derived subsidy funded approximately 900 films. $^{70}$ The U.K. now has among the lowest percentage of subsidized films within the EC. ${ }^{71}$ Financing is still available from British Screen Finance, which distributes about 2 million pounds for feature production

60. Id.

61. Id.

62. Sharon Waxman, Arts of the State: France Tries to Subsidize a Culture, WASH. Post, Oct. 23, 1994, at G1. France is one-fifth the size of the United States but spends more than five times as much to support the arts. Id.

63. Id.

64. Id. The pay-TV service Canal Plus is required to pay a minimum of $18.5 \%$ of its pre-tax revenues to subsidize the movie industry. In exchange, Canal Plus can air French films a year after their release. Id.

65. Id.

66. Id.

67. French TV Producers Launch Promo Drive, BROADCAST, Oct. 21, 1994, at 12.

68. Id.

69. Government "Gutted" Film Industry, SCREEN FIN., July 27, 1994, available in WESTLAW, INT-NEWS-C Database.

70. Id. Film producer David Puttnam contends that cutting the Eady Levy, together with increased tax and licensing costs to independent British television, "gutted" the national production industry. Id. Lower levels of film subsidy in the U.K. have caused a corrosponding dropoff in film production. Moore, supra note 45, at 307.

71. Only $40 \%$ of the 55 UK films in production in the summer of 1994 received a government subsidy. See European Features, supra note 56. 
and development. ${ }^{72}$ British Screen also has a European Co-Production Fund that provides financing. ${ }^{73}$

Germany was one of the top ten EC nations for ratio of subsidized and television-backed films in $1994 .^{74}$ Germany provides subsidies through the Federal Interior Ministry, which dispenses direct grants for film productions. ${ }^{75}$ German state and regional funding is also available. ${ }^{76}$ Additionally, new films may receive interest-free loans from the government. ${ }^{77}$ Every EC Member State maintains some type of government subsidy system. Smaller European nations usually have a higher percentage of subsidized films, but on average produce only about ten films a year. ${ }^{78}$ Italy has the lowest percentage of government subsidy, with only thirty-nine percent of the fifty-six films in production in the summer of 1994 receiving government funds. ${ }^{79}$

\section{EC Subsidies}

At the EC level film financing support is administered primarily by the "Measures to Encourage the Development of Industry of Audiovisual Production" (MEDIA 95) program. ${ }^{80}$ MEDIA 95 is a five-year "action program" intended to support production and distribution of European audiovisual material through seed money, loan guarantees, financial investment stimulus, and industry cooperation. ${ }^{81}$

72. Moore, supra note 45 , at 306.

73. Id.

74. See European Features, supra note 56.

75. Moore, supra note 45. Additionally, Filmforderungsanalt gives grants for scripts, short films, children's films, and documentaries. Id.

76. Id.

77. Id. Most of these subsidies are given in relation to participation by German citizens, but regional awards may be made on purely economic criteria. Id.

78. The top European countries (both in and out of the European Community) by ratio of subsidized films in production during the summer of 1994 include Austria - 12 of 12 films, Bulgaria - 5 of 5 films, Greece - 13 of 13 films, Portugal - 9 of 9 films, Finland -6 of 6 films, Poland - 8 of 8 films, Denmark - 9 of 10 films, Belgium - 7 of 8 films, and Switzerland 12 of 12 films. European Features, supra note 56.

79. Id.

80. Eurimages, the Council of Europe's (CE) co-production support fund, also offers limited distribution aid to CE member states who are not part of the EC. Media Fosters Eurodistribution Groups, SCREEN FN., Sept. 9, 1994, available in WESTLAW, INT-NEWS-C Database. In 1992 the budget of Eurimages was approximately 21 million Ecus. Id.

81. COOPERS \& LYBRAND, supra note $23, \S 6$. Media 95, which covers the years 1991-95, is the third phase of an initiative to make the European film and television industries competitive on the world market. See Garrett, supra note 4, at 558. The first two phases, encompassing industry consultation and development of a pilot program, were inaugurated under MEDIA 92. Id. See also Council Decision 90/685/EEC of December 21, 1990 concerning the 
Much of MEDIA 95's work is handled by sub-agencies known as actionlines. Currently MEDIA 95 has nineteen action-lines, covering initiatives as diverse as script development, animation, film dubbing, documentaries, and media business education. ${ }^{82}$ A pending reorganization of the program will reduce and consolidate the number of action-lines to nine. ${ }^{83}$ Three actionlines, the European Film Distribution Office (EFDO), Support for Creative Independent Production Talent (SCRIPT), and the Media Business School, ${ }^{84}$ have been singled out as "senior" initiatives, and would each administer two "junior" action-lines in the planned reorganization. ${ }^{85}$

EFDO offers matching funds for film distribution costs in any three EU countries to a cap of 100,000 Ecus $\left(121,140\right.$ U.S. dollars) per country. ${ }^{86}$ The maximum distribution subsidy from the EFDO is 300,000 Ecus for prints and advertising. ${ }^{87}$ EFDO has recently been allocated additional funds to foster creation of regional distribution consortia. ${ }^{88}$

Previous efforts to create European distributor joint ventures have met with limited success. ${ }^{89}$ Political difficulties obstruct the building of cross-nation distribution ventures, as local marketers are reluctant to surrender control of their individual fiefdoms. ${ }^{90}$

implementation of an action program to promote the development of the European audiovisual industry, 1990 O.J. (L 380) 37 [hereinafter MEDIA 95].

82. See COOPERS \& L YBRAND, supra note $23, \S 6$ (discussing the various MEDIA 95 action-lines in detail).

83. Media's Nine-Line Plan Gives Star Roles to SCRIPT, EFDO, and MBS, SCREEN FIN., Mar. 23, 1994, available in WESTLAW, PTS-NEWS Database [hereinafter Media's NineLine Plan].

84. The Media Business School in Madrid, Spain, coordinates and co-finances training, workshops, seminars, and research to improve the economic environment of the European audiovisual sector. See COOPERS \& LYBRAND, supra note 23 , at $\S 6.10$.

85. Media's Nine-Line Plan, supra note 83.

86. U.S. Pic Makers Seek Ways, Coin to Go Int'l, supra note 49.

87. Id. The Disney subsidiary Miramax has previously received EFDO funds for the distribution of "Enchanted April" and "The Crying Game." Id.

88. The EFDO in conjunction with two other MEDIA 95 action-lines, Espace Video Europeene and Europa Cinemas, is administering the "Distribution Plus" plan, initiated in Sept. 1994. Media Fosters Euro-distribution Groups, SCREEN FIN., Sept. 9, 1994, available in WESTLAW, INT-NEWS-C Database. The plan provides funds to promote creation of regional distributor collaborations for film distribution across Europe. Id. At least five European countrits are involved. The "Distribution Plus" plan is intended to challenge American distributors, which now hold an eighty percent share of the European market. Id. Restricted funds (about 200 million Ecus), and the pending expiration of the MEDIA 95 program makes the prospective impact of the "Distribution Plus" plan questionable. Id.

89. Id.

90. CIC Opts for Localized Strategy, MARKETING, Nov. 3, 1994, available in WESTLAW, INT-NEWS-C Database. 
SCRIPT is a fund dedicated to improving the quality of screen and musical writing in the EC by providing loans to cover the cost of screenplays and pre-production for dramatic films. ${ }^{91}$ SCRIPT supports projects likely to attract audiences in at least two separate EC countries, and preference is given to projects co-developed by nationals from at least two different Member States. ${ }^{92}$

Audiovisual Eureka was created in October 1989, to stem the flow of program purchasing funds out of Europe. ${ }^{93}$ Twenty-six European governments and the EC participated in the creation of Audiovisual Eureka, with the objective "to invigorate the European market by favoring the establishment of a network of partners around concrete projects, from their creation up to the distribution of audiovisual and cinematographical works." ${ }^{194}$ It is not a direct funding subsidy, but distributes information and coordinates meetings to improve access to other public and private financing mechanisms. ${ }^{95}$ Audiovisual Eureka offers support for producers, broadcasters, and distributors to find partners for co-productions, and help in collecting funds for budget completion. ${ }^{96}$

EC and Member State subsidies have spent billions of dollars to support the production and distribution of European films and television programs. However, there has not been a resulting improvement in quality or market reach. ${ }^{97}$ Even persons within the European industry are beginning to acknowledge the failure of the subsidy system, but the general consensus is that the present weakness of the audiovisual sector demands increased financial support. $^{98}$

\section{Proposed Changes to EC Audiovisual Quota AND SUBSIDY LEGISLATION}

European audiovisual officials are acutely aware of the need to find solutions to the industry's poor performance. In April 1994, the Directorate General X (DG-X), responsible for European cultural issues, published a set

91. COOPERS \& LYBRAND, supra note $23, \S 6.7$. SCRIPT offers loans to writers and writer/producer teams. Id.

92. Id.

93. Audiovisual Eureka Supports Europeian Audio Visual Industry, HDTV REPORT, Apr. 27, 1994, available in WESTLAW, INT-NEWS-C Database.

94. Id. Audiovisual Eureka has a permanent secretariat in Brussels. Id. Its role is to inform the audiovisual professionals and the general public on multi-state initiatives, provide information on projects in EU countries, and help European producers proposing projects to assemble a marketing presentation, find possible partners, and get financial support. Id.

95. Id.

96. Id.

97. See discussion infra part IV(C).

98. See European Features, supra note 56. 
of audiovisual industry concerns known as the "Green Paper."199 In putting the paper together, the DG-X solicited input from independent sources. ${ }^{100}$ The predominant problems cited by these sources included the lack of a coherent EC policy and the absence of an efficient Europe-wide film distribution network. ${ }^{101}$ Increased protectionism and EC monetary support was almost exclusively the suggested response. ${ }^{102}$

Notably the DG-X declined to endorse proposals for greater protectionism submitted by independent sources. ${ }^{103}$ Rather than recommending new barriers to non-EU productions, the Green Paper poses questions about future policy alternatives ${ }^{104}$ The Green Paper bases its discussion on an analysis of the thirty-year decline in the European audiovisual sector, new technologies which are revolutionizing the industry, and the importance of supporting the industry in terms of economics and culture. ${ }^{105}$ The Green Paper recommends building upon the TWFD and the MEDIA 95 program to pursue these policy interests. ${ }^{106}$

99. See Strategy options to strengthen the European Program Industry in the context of the Audiovisual Policy of the European Union-Green Paper, COM(94)96 final [hereinafter Green Paper].

100. 'Vague' Green Paper Must Be Reworked, supra note 6. Independent sources submitting information included the European Federation of Audiovisual Filmmakers (FERA), a Brussels based directors lobby, and the "Committee of the Wise," a group of seven prominent European audiovisual industry experts. Id.

101. Audiovisual Production: A Strategy to Create Jobs and European Culture, supra note 9 .

102. The "Committee of the Wise" report recommended tighter entertainment import barriers in the next 10 years, coupled with 2 billion Ecus (about $\$ 2.25$ billion American) in increased industry subsidies. Tom Buerkle, Hollywood to the Rescue as Culture War Abates, INT'L HERALD TRIB., Apr. 8, 1994, available in LEXIS, News Library, CURNWS File. Development of a Europe-wide audiovisual distribution entity was also proposed. Vague Green Paper Must Be Reworked, supra note 6 . In the interim, they suggested subsidies to encourage joint ventures between regional distributors, and to lower cinema print rental costs. Audiovisual Production: A Strategy to Create Jobs and European Culture, supra note 9. Additionally, the committee wants development of a network of European cinemas, with subsidies and loans for those agreeing to dedicate $35 \%$ of their screens to European films. Id. Money for this broad initiative is to come from an EU-wide levy on cinema tickets, video rentals, and broadcasting receipts. Vague Green Paper Must Be Reworked, supra note 6. FERA published a 15-point plan aimed at coordinating film policies across Europe. Id. The plan includes the introduction of a number of pan-European tax incentives to encourage the promotion and distribution of Europear. productions. Id. FERA also urges measures to force all European pay-television channels to invest in European feature production as a prerequisite to licensing. Id.

103. Buerkle, supra note 102.

104. Id.

105. ECOSOC Opinion on Green Paper on Audiovisual Policy, REITERS EC REP., Sept. 28, 1994, available in LEXIS, News Library, CURNWS File.

106. Id. 
Release of the Green Paper was followed by a round of proposals from European audiovisual regulatory groups and lobbyists. Like the pre-Green Paper submissions, most of these proposals centered around strengthening protectionist legislation and expanding EC audiovisual support funds. Although recommendations came from many diverse entities, they generally involved one or more of the following propositions; 1 ) maintaining the division between cultural and commercial trade; 2) tightening and extending the TWFD quota system; 3) organizing, consolidating, and increasing funding for government support programs; 4) improving European controlled cinema distribution; and 5) development of better voice dubbing technology for film.

\section{A. Individual Recommendations by Regulatory Bodies and Interest Groups}

Five European audiovisual regulatory groups met at a conference convened by the DG-X in Brussels to discuss the Green Paper and propose future policies for the industry. ${ }^{107}$ The so-called Brussels coalition proposed doing away with Eurimages and the MEDIA program in favor of a single EC audiovisual fund, with a budget of 1.5 billion Ecus over five years. ${ }^{108}$ The money would be dedicated to a three-prong program to promote television broadcasting, cinema distribution, and creation of new film production and producers. ${ }^{109}$ The fund would provide both "soft loans" with easy repayment terms, and guarantees for loans from financial institutions. ${ }^{10}$

The Brussels coalition also recommended changes to the TWFD language to expand the Article 6 definition of "European works" and make broadcast quotas mandatory. ${ }^{111}$ They seek more specific quotas on prime-time European

107. Five Audiovisual Groups Seek More EU Funds and Changes to the TV Directive, TECH EUR., July 11, 1994, available in LEXIS, News Library, CURNWS File. The attendants at the July 1994 meeting included the Cinematographic Industries Committee of the European Community (CICCE), the European Broadcasting Union (EBU), the producers association Eurocinema, the Federation of European Sound and Vision Industries (FEITIS), and the European Federation of Audiovisual Filmmakers (FERA). Id.

108. Id. The group suggests that the EU provide up to $\mathbf{7 5 0}$ million Ecus of the fund, approximately one percent of the EU's entire budget. Euro-Group Calls for Tougher Quota Rules, SATELLITE TV FIN., July 7, 1994, available in LEXIS, News Library, CURNWS File. The balance would be raised through audiovisual levies. Id. See discussion of the Eurimages initiative, supra note 80.

109. Euro-Group Calls for Tougher Quota Rules, supra note 108.

110. Id. Director of DG-X Joao de Deus Pinheiro noted that he would be against any direct subsidy fund, and favors loan assistance. Id.

111. Five Audiovisual Groups Seek More EU Funds and Changes to the TV Directive, supra note 107. The group wants the TWFD Article 6 definition of "European works" to be expanded to include documentaries and animated films. Id. See discussion of Article 6 infra 
broadcasting. ${ }^{112}$ Non-dramatic programming services such as sports and news should not apply toward meeting the TWFD quota, according to the group. ${ }^{113}$ Finally the Brussels coalition seeks expansion of the TWFD quotas and levies to include new services like pay-per-view. ${ }^{114}$ It was agreed that quotas would not be feasible for services such as video-on-demand and teleshopping, and therefore the group proposed additional taxes on these services. ${ }^{115}$

On September 15, 1994, the Economic and Social Committee on the Strategy Options to strengthen the European audiovisual industry (ECOSOC) released an opinion paper on the issues raised by the Green Paper. ${ }^{116}$ ECOSOC recommended maintaining the division between economic and cultural imports, reasoning that European cultural identity would be lost in "unbounded competition." 117 In this regard ECOSOC stressed the need for more comprehensive regulation for existing and new audiovisual services. ${ }^{118}$ The ECOSOC suggested stepped-up promotional efforts for European productions, concentrating on the best programs produced, with the collateral development of better dubbing technology. ${ }^{119}$

France's powerful industry lobby, Authors/Directors/Producers (ARP), sponsored the Beaune Film Forum in October 1994, to draft recommendations for increased protectionism. ${ }^{120}$ Forum participants proposed making the TWFD broadcast quota system mandatory by removing all flexible language. ${ }^{121}$ ARP further suggested extending quotas to "the new services carried by the

part II(A). The group also calls for the "where practicable" phrase to be removed from Article 4 to make quotas mandatory. Id.

112. Euro-Group Calls for Tougher Quota Rules, supra note 108.

113. Five Audiovisual Groups Seek More EU Funds and Changes to the TV Directive, supra note 107.

114. Id.

115. Euro-Group Calls for Tougher Quota Rules, supra note 108. The Co-ordination of European Independent Producers (CEPI) suggested an alternative plan, in which all broadcasters could choose to meet the TWFD 51\% quota or to invest $20 \%$ of annual income in European originated film production. European Producers to Propose Alternative System of Quotas, BroAdCAST, July 1, 1994, at 3.

116. ECOSOC Opinion on Green Paper on Audiovisual Policy, supra note 105.

117. Id.

118. Id.

119. Id. To finance these efforts the ECOSOC supports a Pan-European levy system. Id.

120. Finding Cure for Euro Woes Sets Tone at Beaune, HoLLYWOOD REP., Oct. 28, 1994, available in LEXIS, News Library, CURNWS File.

121. Beaune Film Forum Calls for Revision of Cross-BorderTV Rules, EUR. CoMMIssion Press Releases, Oct. 31, 1994, available in WESTLAW, INT-NEWS-C Database. 
information highways. "122 They called for levies to be extended to developing audiovisual services, with funds dedicated to supporting film production. ${ }^{123}$

Parties at the Beaune Forum also encouraged doing away with Article 85(3) of the EEC Treaty, which contains exemptions to anti-competition rules allowing European film distribution to be concentrated in non-European countries. ${ }^{124}$ The Article 85 exemption permitted the formation of American distribution organizations such as United International Pictures (UIP), a joint European distribution network representing MGM, Paramount, and MCA/Universal. ${ }^{125}$ The EC exemption given to UIP expired on July 16, 1994. ${ }^{126}$

Most European audiovisual policy-makers, including culture commissioner Joao de Dues Pinheiro, oppose the UIP application for renewal of the exemption. ${ }^{127}$ European industry officials contend that the UIP application should be denied because overall American control of European distribution violates anti-trust laws. ${ }^{128}$ UIP argues that its market share has dropped from twenty-nine percent, considered acceptable by the EC in 1989, to twenty percent in $1994 .{ }^{129}$ Analysts say the final ruling on the application has been delayed because DG-IV can find no sound legal reason to reject it. ${ }^{130}$

UIP and two European co-producers have filed suit against the EC for allegedly requesting the EFDO to delay a decision on a 1994 UIP distribution funding request for two European films, pending the EC ruling on UIP's

122. Id.

123. French Film IndustryWants Guarantees Information Superhighway Will Not Benefit US Films, LES ECHOS, Oct. 31, 1994, at 39.

124. Beaune Film Forum Calls for Revision of Cross-Border TV Rules, supra note 121. See also Treaty of Rome, supra note 55, art. 85(3).

125. UIP Pleads in Favour of Retaining Distribution Rights, REUTER AGENCE EUR., Sept. 20, 1994, available in LEXIS, News Library, CURNWS File.

126. UIP Asks for Distribution Aid as EC Says Bid is too Hot to Handle, SCREEN FIN., Sept. 9, 1994, available in WESTLAW, INT-NEWS-C Database. Although UIP filed for an extension of its exempt status in June 1992, politically motivated delays have pushed a final ruling back to mid-1995. Id. "This is too much of a political hot potato even to consider a timetable, let alone the application itself" said Norbert Menges, a senior official at the competition Directorate General IV (DG-IV). Id.

127. Id.

128. Id.

129. UIP Pleads in Favour of Retaining Distribution Rights, supra note 125. UIP further points out that it has been found by officials of the EC, the UK, Germany, and Denmark, to meet their separate competition regulations. Id. UIP asks the EC to take into account the approximately 150 European films UIP has distributed since 1989, and denies charges of manipulative cinema booking practices. Id.

130. UIP Asks for Distribution Aid as EC Says Bid is too Hot to Handle, supra note 126. 
exemption status. ${ }^{131}$ As noted, the EFDO has previously granted funds to other American distributors promoting European films in Europe. ${ }^{132}$

\section{B. Implementation of the TWFD Changes}

Legislative changes for the TWFD are to be finalized by the end of $1995 .^{133}$ In March 1995, a draft of proposed TWFD changes sponsored by incoming DG-X commissioner Marcelino Oreja was passed by a majority of European Commissioners. ${ }^{134}$ It proceeds to the European Council of Ministers, where intense debate is expected. ${ }^{135}$

The Oreja draft largely follows the changes proposed by predecessor Joao de Deus Pinheiro. ${ }^{136}$ The most significant of these changes is the removal of the flexible "where practicable" language, making the Article 4 broadcasting quota mandatory. ${ }^{137}$ In an effort at compromise, the Oreja draft would put a ten-year time limit on the TWFD quota regime. ${ }^{138}$ It also provides that "thematic channels" devoting more than eighty percent of their broadcast time to one particular type of programming would be given the option of an

131. Filmmakers Take Commission to Court over Funding, REUTER ECON. NEws, Nov. 16, 1994, available in WESTLAW, INT-NEWS-C Database. Co-producer Allied Vision Limited said in a released statement, "Our international distribution plans for 'Nostradamus' have been based on the availability of EFDO support, for which we, the film, and UIP clearly qualify." Id. Producers of the Italian film "Maniaci Sentimentali" are the third party in the suit, which asks the European Court of First Instance in Luxembourg to reverse the EFDO decision. Id. UIP representatives said the petitioning parties needed to file suit in November 1994 to meet a two-month deadline for appealing EC decisions. Id.

132. See discussion supra note 87 and accompanying text.

133. Michael W. Stern, EC Backs French Proposal, Sets Up Heated Debate, VARIETY, Mar. 27, 1995, at 39.

134. Commission Opts for StifferTV Quotas: 10 Years Non-Renewable, EUR. REP., Mar. 24, 1995, available in LEXIS, News Library, CURNWS File. The TWFD draft changes passed by vote of 15 to 5 . Id. Commissioners voting against it included Sir Leon Brittan, Hans van der Broek, Martin Bangemann, Monika Wulf-Mathies, and Anita Gradin. Id.

135. Stern, supra note 133, at 39.

136. Commissioner Pinheiro stated he wanted to remove the "ambiguity" from the TWFD. Brussel's TV on the Blink, supra note 7.

137. Id.

138. Id. Initially, the 10-year limitation has not found support from either side. Parties against the TWFD quota point out that, given the rapid changes in broadcast and related media, ten years will be about the useful period of any rule. Stern, supra note 133. Those in favor of protectionism decry the time limitation as a misguided commitment to abandon the cultural exception. Commission Opts for StifferTV Quotas: 10 years Non-renewable, supra note 134. 
"investment quota" rather than a content quota. ${ }^{139}$ The Oreja draft would allow thematic channels the alternative of committing twenty-five percent of the channel's production budget to "European" productions. ${ }^{140}$ All broadcasters are given a three-year grace period to comply with the new mandatory quota rules once they are adopted. ${ }^{141}$

Instead of broadening the scope of the TWFD quotas to include newer services such as interactive and pay-per-view channels, additional research and planning toward a separate regulatory framework has been suggested..$^{142}$ The concern is that premature or ill-conceived legislation could have a negative impact on the development of these so-called "information society" services. ${ }^{143}$ However, at present, individual member states remain free to regulate developing communication services. ${ }^{144}$

The incorporation of strengthened financial subsidies and support mechanisms for European productions is also expected. A levy on telecommunications services is being considered. ${ }^{145}$ The restructuring of the MEDIA program is also seen as a possible avenue for increased film production subsidies. ${ }^{146}$

In the foreseeable future, it appears that proponents of increased protectionism will prevail. The Oreja draft of proposed changes would remove all flexibility from the TWFD regime of broadcast quotas. Although it has a long journey to final ratification, the Oreja draft has found broad initial support

139. Id. Examples of "Thematic channels" include movie services such as Filmnet, ARTE, and Canal Plus. Id.

140. Id. Presumably, this means European Works, as defined by TWFD Article 6. See discussion supra part $\mathrm{V}(\mathrm{A})(2)$.

141. Id.

142. Information Society: Martin Bangemann Argues Against Premature or Excessive Regulation, MONTHLY REP. ON EUR., Apr. 26, 1995, available in LEXIS, News Library, CURNWS file. This plan was proposed by DG-X Commissioner Oreja, Internal Market Commissioner Mario Monte, and European Telecommunications Commissioner Martin Bangemann. Id. The research would involve the generation of four Green Papers in the areas intellectual property rights, legal protection of coded transmissions, commercial communications, and the development of new services. Id.

143. Id.

144. EU may tighten TV Quota Rules, DAILY VARIETY, Oct. 27, 1994, at 31.

145. Commission Opts for Stiffer Quotas: 10 Years Non-Renewable, supra note 134.

146. France Postpones Debate on Broadcasting Quotas until June, MONTHLY REP. ON EUR., Apr. 25, 1995, available in LEXIS, News Library, CURNWS File. 
within the EC. ${ }^{147}$ In fact, the most adamant opposition in Europe has come from those who see the Oreja draft as too lenient. ${ }^{148}$

\section{THE ECONOMIC AND TECHNICAL REALITIES That Will DEFEat Protectionism}

Quotas and subsidies clearly do not provide a long-term solution to Europe's weak audiovisual industry. Even the drafters of the Green Paper recognize "an urgent need to restructure an industry [able to] survive without protectionism and without subsidies."149 But, as discussed, the direction of most current legislative proposals is toward increased protectionism, rather than progressive restructuring. By preserving and reinforcing the status quo, the EU is missing a rare opportunity to direct expansion by a controlled opening of its market. Social and economic forces are already severely straining the present protectionist system. The only question which remains is when the system will collapse and what will be left afterwards.

\section{A. Europe's Inability to Meet Programming Demands of New Technology}

Europe currently does not produce enough audiovisual product to meet its market needs. During July of 1994, European producers had 510 films in some stage of production. ${ }^{150}$ This included films currently being filmed, in post-production, and awaiting release. ${ }^{151}$ An average of 500 films are produced in Europe each year, whereas over 1,000 film distributors service the European market. ${ }^{152}$

147. Commission Opts for Stiffer TV Quotas: 10 Years Non-Renewable, supra note 134.

148. Id. French audiovisual lobbying groups have asserted that the 10-year limit will "systematically dismantle idea of the cultural exception." Id. Representatives of Eurocinema took issue with the "investment quota" alternative for thematic channels. Id. Eurocinema also supports broadening the scope of the TWFD quota regime to include newer services such as pay-per-view. Id.

149. Vague Green Paper Must Be Reworked, supra note 6. See also Green Paper, supra note 99 .

150. European Features: 510 in Production, Another 2,271 in Development, supra note 56.

151. Id. The top four producer nations represented approximately $51 \%$ of total production including France with 91 films, Germany with 60 films, Italy with 56 films, and the UK with 55. Id.

152. Lambert, supra note 8 , at 10. 
Further, European broadcasters need 16,000 hours of dramatic and comedic programming each year, but current production levels are barely at 2,500 hours. ${ }^{153}$ Ira Goldman, Trade Representative to the Governor of California, points out that if technological changes proceed, there will never be enough audiovisual product to fill the demand. ${ }^{154}$ "Unfortunately, there are some who do not seem to want a solution, and it is up to us to persuade them otherwise." ${ }^{155}$ It is not realistic to expect European producers to meet the immediate market need, let alone the inevitable increase in demand created by new audiovisual services. ${ }^{156}$

The lower prices of American programming are pushing open the European market. To meet TWFD standards, European broadcasters need a great deal of European product. ${ }^{157}$ Therefore, demand is higher for "European works," and broadcasters must pay more for quality European productions than for American films that are as good or better. ${ }^{158}$ Hollywood has a huge stock of films, and it is much less expensive to buy American imports than to produce new material. ${ }^{159}$ Prices are also lower because of competition between American distributors for the European market. ${ }^{160}$ Former chairman of Britain's GMTV, Greg Dyke, claims, "The British audience much prefers British drama, " but new channels playing mainly American entertainment will make it "more advantageous for commercial television to get a smaller audience but pay far less for [American programs]." ${ }^{161}$ With the continued growth of audiovisual media and major investments at stake, economics will force media services to break with the TWFD quota regime. ${ }^{162}$

153. Quintero, supra note 43.

154. Griffiths, supra note 18, at 40.

155. Id.

156. Beatrice Le Fraper Du Hellen, French Cultural Attache to the United States has noted that if French television stations were forced to meet that country's quota of airing $60 \%$ European works, the broadcasters would go bankrupt. Vernon Scott, French Attache Seeks U.S. Market, UPI, Oct. 24, 1994, available in LEXIS, NEWS Library, CURNWS File.

157. Setlowe, supra note 49.

158. Id.

159. Scott, supra note 156.

160. Id.

161. Martina Devlin, Limits on American TV Imports Urged, PRESS ASS'N NEWSFILE, July 13, 1994, available in LEXIS, News Library, CURNWS File.

162. Lowell Forte, Film Industry Lefi Out of Landmark Trade Pact, CORP. LEGAL. TIMES, June 1994, at 14. American Film Marketing Association (AFMA) counsel Edward S. Labowitz, asserts broadcasters "will say, 'get out of our way with these stupid quotas.' The future will write its own history, with the European television broadcasters telling the governments to go to hell." Id. 


\section{B. The Expansion of Media Services in Europe}

Quite a few audiovisual advancements are on the horizon for Europe. France is currently considering a 40 billion dollar "autoroute d'information," wiring every French household with fiber optic cable by $2015 .{ }^{163}$ British Telecom will begin testing an experimental "information highway" style interactive system in 1995 on 2,500 homes in East Anglia, U.K. ${ }^{164}$ In addition to television programs and films, the system will offer customers the chance to schedule vacations, do shopping, and buy books without leaving home. ${ }^{165}$ In Europe, the conversion to digital terrestrial television is in the final stages of development. Digital television is expected to offer viewers a wide assortment of channels to choose from, including crime, sports, "thematic channels," and movie channels. ${ }^{166}$

The challenge to broadcast quotas by new technology is already evident in the area of satellite services. Existing communication satellites can beam a single signal to most of Europe. Existing licensing procedures limit licensing satellite services to a territory-by-territory basis. ${ }^{167}$ However, "in a Europe committed to free trade, decoders will become readily available," says Edward Labowitz, council for the American Film Marketing Association (AMFA). ${ }^{168}$ Importantly, home dishes will not be under TWFD quota controls in the foreseeable future. ${ }^{169}$

The alien invader beaming down from space to menace European culture is Ted Turner. His satellite stations, Turner Network Television (TNT) and the Cartoon Channel, together with Rupert Murdock's Sky One, have flouted European content quotas since their inception. ${ }^{170}$ Turner has lobbied for greater access, meeting with French President Francois Mitterrand to argue for TNT distribution in France and Europe. ${ }^{171}$ Currently, the channel is

163. Fred Brenchley, Crash Ahead on Superhighway-Multi Media, AUSTL. FN. REV., Oct. 31, 1994, at 12 .

164. Ross Tieman, BT Offers Families the Chance to Dial $M$ for Movies, LONDON TIMES, Nov. 16, 1994, available in WESTLAW, INT-NEWS-C Database.

165. Id. Users will be able to choose services from a menu on their television screens. Id. The system functions without interfering with normal telephone lines. Id.

166. Mike Jones, Allen Foresees Channel Boom in Wake of Digital, BroADCAST, Nov. 4, 1994, at 1 .

167. Forte, supra note 162 , at 14.

168. Id.

169. Quintero, supra note 43.

170. Devlin, supra note 161 .

171. Brussels Considers Quota Deal as UK Row Looms, supra note 35. Turner has also met with Alain Carignon, French communications minister, and Jacques Boutet, president of the French regulatory body, Conseil Superieur de l'Audiovisuel (CSA). Id. 
banned from France's cable networks because of its all-American content. ${ }^{172}$ Turner is also pursuing audiovisual production and cinema distribution expansions in Europe. ${ }^{173}$

The U.K. government has been at odds with the EC over licensing of satellite channels, such as Sky Movies, TNT, and the Cartoon Network. ${ }^{174}$ Department of National Heritage Secretary Peter Brooke said in April 1994 that "the U.K. would seek a clarification of the wording in its favor [sic] if the commission did not agree that the present directive allows for the flexibility which the U.K. perceives to exist." 175 The U.K. wants to preserve the linguistic accommodations of the TWFD, allowing quotas to be imposed "where practicable and by appropriate means" and "progressively, on the basis of suitable criteria." ${ }^{\text {176 }}$ The November 1994 draft of changes to the TWFD proposes removal of this language, but would give satellite channels five years to comply with the fifty-one percent quota. ${ }^{177}$

The DG- $X$ has excluded interactive services such as video-on-demand and pay-per-view from its 1995 changes in the TWFD quota regime. But the draft changes left an ominous loophole; individual governments would have the right "where they consider it necessary for purposes of language policy" to "lay down more detailed or stricter rules." ${ }^{\text {178 }}$ Before the "information superhighway" can go forward, comprehensive pan-European laws must be developed. Experts believe that without a solid legal framework, regional rules will surface that fragment the market and make it unworkable. ${ }^{179}$

European audiovisual experts see evolving technologies as a route to circumvent broadcasting quotas. ${ }^{180}$ Thus, those concerned with American "cultural imperialism" have a vested interest in maintaining and increasing

172. Id.

173. In 1994, Turner established Turner Productions SA, a Paris-based film production company. New Film DistributionNetworks in Offing, SCREEN DIG., June 1994, available in LEXIS, NEWS Library, CURNWS File. Turner Broadcasting is also organizing a global distribution network through its Castle Rock Entertainment subsidiary. Id.

174. Marlene Edmunds, EC Plans Quota Respite - Satellite and Cable Channels, BROADCAST, Nov. 4, 1994, at 10.

175. Brussels Considers Quota Deal as UK Row Looms, supra note 35.

176. Id. See also discussion of controversy between EC and UK, supra notes 28-37 and accompanying text.

177. Edmunds, supra note 174, at 10. See also discussion of proposed TWFD changes supra part III(B). The draft changes also suggests that individual EU Member State governments could impose budget levies instead of quotas. Edmunds, supra note 174, at 10.

178. Brussel's TV on the Blink, supra note 7.

179. Intellectual Property: 'Information Society'Leads EU to Begin Intellectual Property Study, BNA INT'L TRADE REP., Aug. 31, 1994.

180. Notebook, Television Dig., July 18, 1994, at 3. 
regulatory roadblocks to expanding audiovisual services. ${ }^{181}$ The very success of American entertainment creates fear of the freedom of choice technology may bring. Access to many components of existing telecommunications media are priced out of reach by regulatory tariffs. ${ }^{182}$ Moreover, material distributed over government controlled communications networks may lend itself to increased control. ${ }^{183}$ The dream of technological freedom could give way to a reality of technological bondage. ${ }^{184}$ Generally, the lack of stable legislation for new technologies will discourage high-tech firms from investing in the necessary infrastructure and equipment. ${ }^{185}$

In France, the effect of protectionist legislation on developing audiovisual services is already apparent. Over-regulation has significantly impaired the development of French cable television. Whereas 13.5 million German homes have cable, including some 800,000 in former East Germany, just under 1.3 million French households were connected to cable networks at the end of 1993, out of a total of nearly 5.3 million homes where cable is available. ${ }^{186}$ The largest cable network in France, Lyonnaise Communications' Parisian network, is not expected to break even until the end of 1995, almost a decade after its commercial launch. ${ }^{187}$

Currently, French satellite, cable, and terrestrial television channels cannot show most feature films on Saturdays, or before 10:30 on Wednesday and Friday nights. ${ }^{188}$. This measure is intended to shore up weak movie theater

181. Jube Shiver, Jr., Wiring the World/The New Age of Global Telecommunications..., LOS ANGELES TIMES, July 26, 1994, at 7.

182. Id.

183. Id.

184. Id.

185. Copyright holding authors are also concerned about proposals to grant broadcasters proprietary rights to programming. Intellectual Property: 'Information Society' Leads EU to Begin Intellectual Property Study, supra note 179. Broadcaster rights in transmitted programming are part of the doctrine of "neighboring rights," and are provided for in the Uruguay Round Accord. See Final Act Embodying the Results of the Uruguay Round of Multilateral Trade Negotiations, Agreement on Trade-Related Aspects of Intellectual Property Rights, including Trade in Counterfeit Goods (TRIPS), opened for signature Dec. 15, 1993, Doc. No. MTN/FA II-A1C. Until the longterm effects are proven, any dramatic change in European intellectual property laws will likely chill market interest in copyright holders. Intellectual Property: 'Information Society' Leads EU to Begin Intellectual Property Study, supra note 179.

186. Kenneth S. Hart, Duel to the Death? Cable Television Industry in France, CoMM. INT'L, May 1994, at 7.

187. Id. Lyonnaise Communications' Paris has only 150,000 subscribers in a city of over 2 million residents. Id.

188. Id. French satellite, cable, and terrestrial channels include TF1, M6, France Television 2/3, and Canal Plus. Id. The pay-television service Canal Plus has seen widespread success, in large part because of more flexible broadcast rules, provided in return for payment of $18.5 \%$ of Canal Plus' pre-tax revenues to subsidize the French film industries. Waxman, supranote 
attendance. Combined with national content quotas, the result is that cable channels cannot distinguish themselves from broadcast TV by offering more films or thematic programming. ${ }^{189}$ Unless some broadcast restrictions and quotas are dropped, French cable television companies may be pushed out of the market. ${ }^{190}$ In the age of digital satellite and cable services, says French Senator Jean Cluzel, French regulatory efforts to maintain a balance between cultural identity and technological innovation are becoming "more and more illusory." 191

Preliminary industry surveys indicate that development of interactive shopping and video-on-demand services in Europe will lag ten years behind the United States. ${ }^{192}$ The lag is attributed primarily to lower interest in the new services, rather than technological hurdles. ${ }^{193}$ Given the general lack of quality viewing options in programming now broadcast in many European nations, audience cultivation also seems to be an issue. ${ }^{194}$ By American standards, the quality of programming shown on European broadcast television approaches the unwatchable. ${ }^{195}$ Cable TV and pay-per-view are making the first inroads to broadening viewer taste. ${ }^{196}$

\section{The Comparatively Low Quality of European Audiovisual Product}

Myron Karlin, president and CEO of Motion Picture Export Association of America (MPEAA), caused an uproar at the international panel discussion of the 1994 World Film Festival when he stated bluntly:

Withdraw from your markets? Like hell! We're not going to do it. Throw up barriers? We'll jump them. Protectionism is not the answer. Make films people want to see. [There isn't any]

62 , at $\mathrm{G} 1$.

189. Hart, supra note 186 , at 7 .

190. Id. Negotiations were initiated in 1994 between the Ministry of Communications, the CSA, cable companies and French film producers to loosen broadcast regulations for both analog and upcoming digital cable services. Id.

191. Id.

192. Interactive Shopping, Video-On-Demand in Europe to Lag U.S. by a Decade, EUROMARKETING, Nov. 1, 1994, available in WESTLAW, INT-NEWS-Database.

193. Brenchley, supra note 163.

194. See Matt Baker, Pic ' $N$ ' Mix Viewing-Pay-TV, BrOADCAST, Oct. 21, 1994, at 18. Baker feels that in the U.K. viewers will need to be educated about the advantages of expanded media services. Id.

195. See Greg Farrell, Culture Schlock; Television Programs in Europe, MEDIAWEEK, July 18, 1994, at 14 .

196. Baker, supra note 194 , at 18. 
European-American film problem .... There is a European film problem. People in those countries don't want to see their own product. ${ }^{197}$

European filmmakers attempting to penetrate the American market have had a notorious lack of success. ${ }^{198}$ European officials attribute this to American provincialism and indifference to foreign cultures. ${ }^{199}$ Some believe it is poor response to dubbed and subtitled films. ${ }^{200}$ European Director Roman Polanski has stated that "[i]f we made better films in Europe, there would be no problem."201 EC's audiovisual commissioner, Juao Pinheiro, has also criticized the European cinema industry's failures "to produce films that meet public expectation and to implement a real commercial strategy able to boost film production." 202

From the perspective of the American audiovisual industry, Europeans stress creative interests at the expense of pursuing business interests. ${ }^{203}$ Europeans, especially the French, view cinema as an art form. ${ }^{204}$ Conversely, Hollywood operates at a more commercial level, best described by the Hollywood axiom, "[i]f making movies were art, it would be called 'show art' rather than 'show business'."205 The divergent attitudes of the U.S. and Europe regarding audiovisual commodities form the crux of the commercial versus cultural trade controversy. ${ }^{206}$

The European subsidy system is actually detrimental to product quality, according to AMFA counsel, Edward Labowitz. "I've seen the projects developed by these subsidy-seeking producers," asserts Labowitz. "What they create are projects and scripts that will appeal to the intellectuals within the subsidy bureaucracies of their respective countries. ${ }^{1207}$

The current situation in the highly subsidized French audiovisual industry supports this assertion. The Centre National de la Cinematographie (CNC)

197. Kirk Honeycutt, MPEAA Pulls No Punches in Fest "Free-for-All," HOLLYWOOD REP., Aug. 31, 1994, available in LEXIS, News Library, CURNWS File.

198. Scott, supra note 156.

199. Id.

200. Id.

201. Hift, supra note 16 , at 13.

202. Forte, supra note 162, at 14.

203. Pia Farrell, Finding Cure for Euro Woes Sets Tone at Beaune, HollYwOOD REP., Oct. 28, 1994, available on LEXIS, News Library, CURNWS File (quoting AFMA president Jonas Rosenfield).

204. Scott, supra note 156 (quoting French Attache Beatrice Le Fraper Du Hellen's assertion that film is part of the art and culture which forms French national identity).

205. Forte, supra note 162, at 14.

206. See Braun \& Parker, supra note 3, at 171.

207. Forte, supra note 162 , at 14. 
expects to receive over 1.92 billion Francs in 1994 from direct state aid, as well as taxes levied on movie tickets, television stations, and video cassettes. ${ }^{208}$ CNC bureaucrats channel the money to French movie and television producers. $^{209}$ In October 1994, a special report by the Cour des Comptes blasted the CNC for "management without any rigor" and for subsidizing "projects that were not marketable" and others that "clearly should not have benefited" from public funds. ${ }^{210}$ Further, French officials have criticized the intimate association the $\mathrm{CNC}$ maintains with French audiovisual producers, represented by the Bureau des Liaisons de l'Industrie Cinematographie (BLIC). ${ }^{211}$ The cozy alliance between BLIC and the CNC has created a stale, anti-competitive environment in the French audiovisual industry. ${ }^{212}$

Moreover, the French subsidy system has tended to create dependency, as the industry becomes unable to function without government support. Recent small cuts in audiovisual funding have met with bewilderment and disbelief on the part of French filmmakers. ${ }^{213}$ And despite the overall high level of subsidies, the number of French moviegoers has fallen by almost thirty-seven percent, from 175 million in 1984 to 110 million in $1994 .^{214} \mathrm{~A}$ government-ordered investigation of the film industry concluded that fully half of the 100-plus French films produced each year are made because there is government money to be spent, not because they ought to be made. ${ }^{215}$ "Forget, forget, forget, the French example," says commercial station TF 1 executive Etienne Mourgeotte. "French regulation is counterproductive."216

208. Hart, supra note 186, at 7.

209. Id.

210. Id.

211. Id. Phillippe-Olivier Rousseau, an official at the Conseil Superieur de l'Audiovisual (CSA), decries the tightly knit clan of French audiovisual producers represented by BLIC as an "inbred, state-run lobbying group" that wields enormous influence over the French mass media. Id. Another analyst describes the tight BLIC-CNC relationship as a nationalized "quasi-Mafia" that prevents new talent from entering the market. Id.

212. Id. American investigative journalist Marc Hunter says the French system "creates interlocking circles in which everybody owes something to everybody else. There's no criticism and not much movement, and the public becomes really irrelevant to what's produced. Except they pay the taxes." Waxman, supra note 62, at G1.

213. Waxman, supra note 62, at G1. When Jacques Toubon became France's Minister of Culture in 1993, he eliminated a $\$ 2.5$ million movie fund established by his predecessor, Jack Lang. Id. However filmmakers kept coming to his office, looking for $\$ 10,000$ to finish a script treatment, $\$ 50,000$ to get through production, a quarter-million to get a project going. Id. "They had gotten used to this, and they didn't understand that there was no more money," says Hubert Astier, Toubon's cabinet director. Id.

214. Id.

215. Id.

216. Tom Buerkle, Can a Divided Industry Conquer?; European Filmmakers Find Little Common Ground, INT'L HeRALd TRIB., July 2, 1994, Finance Section. 
European product is often limited to a regional appeal because of cultural diversity and language barriers. EC Commissioner Pinheiro claims, "The situation in Europe is different and will remain so if only because nine official languages are spoken. Thus, the European film industry faces serious difficulties to define its public."1217 The United States has succeeded by using a onemarket approach to the entire European continent. "Do the American's make better films?" international filmmaker Dino De Laurentiis posed. ${ }^{218}$ "Absolutely not, they simply have the merit of believing in a single European market."219 Besides European familiarity with American culture, the single market approach works because of the widespread use of English. Throughout the world, English has become the international method of expression. ${ }^{220}$ In science, in business, in diplomacy, on television, radio, and movies, English is a transcultural medium, allowing diverse peoples brought together by modern technology to interact. ${ }^{221}$ Thus, a film produced in English has a much broader potential audience than a French or German language film.

\section{A Workable Plan to Resuscitate THE EU AUDIOVISUAL INDUSTRY}

American audiovisual production continues to be the standard by which European work is measured. European producers seek to co-opt the American pedigree that establishes "hit" status. For example, U.K. backed filmmaker British Screen releases many of its movies in the United States before they are shown in Britain, because of the lack of initial interest in British audiences. ${ }^{222}$ Chief executive Simon Perry points to British Screen's "The Crying Game," as an example of how films flounder in the U.K. before they take off in America. ${ }^{223}$ Only when a film's reputation had been made in the United States does the film fare better in Britain. ${ }^{224}$

To become a true contender in the audiovisual market, Europe must follow a two-step course of action. First, Europe needs to increase production

217. Forte, supra note 162 , at 14.

218. Buerkle, supra note 216.

219. Id.

220. Michael Rezendez, English as the Global Language from Poles to Poles, It's Now on the Tip of a Billion People's Tongues, Boston GLOBE, Nov. 6, 1994, at 82.

221. Id.

222. Richard Brooks, UK Filmgoers Regarded as Box-Office Flop, OBSERVER, Oct. 30, 1994, at 13.

223. Id.

224. Id. "Four Weddings and a Funeral" is another recent film that flopped in the UK before it did so well in America that the British media took notice. Id. It is now the most profitable British film ever, with receipts so far of 25 million pounds. Id. 
of commercial-quality films that can gain access to the American audience. The fastest way to achieve this goal is co-production with American financial partners. The subsequent supply of quality product will rejuvenate Member State audience interest, allow for audiovisual communications technology expansion, and build the infrastructure of an international production center. ${ }^{225}$ It is not necessary for European producers to surrender creative control to their American financial partners; such cultural concerns can be protected through carefully drafted co-production regulations.

Once the structures are in place to create and market profitable productions, the major European finance centers will be ready to take the next step and assume control of the funding aspect. ${ }^{226}$ Daniel Marquet, president of the France's Studio Canal Plus, agrees with the need to collaborate with American studios:

We cannot avoid becoming an industry to survive in Europe. Ride on the strength of what [Americans] do best. Build strong product and cooperate with the majors, using their strength and knowledge of distribution. ${ }^{227}$

In contrast, the United Kingdom already has the film talent and production facilities to succeed in the American market. ${ }^{228}$ Veteran British film producer Barry Spikings, now working in Hollywood, sums up the situation, "The U.K. has talented people who make films. It does not, however, have a regular supply of finance to fund film production. ${ }^{1229}$ The reason is that worldwide distribution, which generates a majority of film revenue, is controlled by major Hollywood studios. ${ }^{230}$ U.K. film production is thus dependent on investment by American distributors. ${ }^{231}$ The problem is that as long as U.S. producers

225. To grow and gain wider distribution, American independent filmmakers have found it necessary to form alliances with major studios analogous to those suggested here for European filmmakers. See Rick Setlowe, Allied Forces Invade H'Wood; Studios, Indies Mutually Dependent in Ever-Changing Field, DAILY VARIETY, July 20, 1994, available in LEXIS, News Library, CURNWS file (describing the modern amalgamation of major studios and independent filmmakers).

226. Movie marketing and finance consultant Seth Willenson similarly asserts, "As foreign entertainment-information conglomerates reach the size where they really want to become competitors in the international market, foreign financing [will] become even greater." Setlowe, supra note 49.

227. Honeycutt, supra note 197.

228. Recent successful UK productions include "Damage," "Four Weddings and a Funeral," and "The Crying Game." See Brooks, supra note 222, at 13.

229. Griffiths, supra note 18 , at 40.

230. Id.

231. Id. 
put up the production money, no profits return to the British film industry. ${ }^{232}$ Spikings contends that it is time for London financiers to take the second step and

[i]nvest in movies at home and abroad on terms which reflect the needs of the U.S. studios to put in place long-term strategic alliances. [ ] The U.K. [can then] take advantage of the worldwide distribution systems [already] created. ${ }^{233}$

Before European backers take on large-scale financing of film production, the European film industry must demonstrate the ability to sustain a competitive level of quality production. So far the huge sums of money infused by the EC and Member State governments have failed to create any consistence of quality. Consequently, the task must fall to private sector entities that have the money and experience to compete. The American film industry is uniquely suited to meet these needs. However, the confusion of regulations governing EC co-productions is proving to be a serious impediment to cooperative efforts between the United States and Europe.

\section{A. Legislative Hurdles to Co-Production}

American producers are eager to get EC co-production status for their films, because it greatly increases access to the EU market. ${ }^{234}$ Co-production also provides an avenue to European subsidies, quota incentives, and tax deals. ${ }^{235}$ But international co-productions tend to be extremely complex deals that are difficult to execute, and European co-production regulations only exacerbate the problem. ${ }^{236}$

During the summer of 1994 only thirty-one percent of all European films were international co-productions. ${ }^{237}$ Almost half of these are intra-European ventures, where different co-production definitions can lead to double and triple counting. ${ }^{238}$ For instance, excluding over-counting from 1993 film production figures revealed only twenty-seven percent of films were co-

232. Id.

233. Id. To this end, UK government officials are contemplating abolishing the withholding tax on motion picture artists and allowing a $100 \%$ capital allowance for the year of investment. Id.

234. U.S. Pic Makers Seek Ways, Coin to Go Int'l, supra note 49.

235. Id.

236. Id. "Co-productions are a wonderful, wonderful premise that, in fact, are very difficult to execute historically," notes Steven Bickel, President of Samuel Goldwyn International. Id.

237. European Features, supra note 56.

238. Co-Production in Europe, SCREEN DIG., July 1994, available in WESTLAW, INTNEWS-C Database. 
productions, as opposed the original estimate of thirty-six percent. ${ }^{239}$ Of the 1993 European co-productions, 59.5\% had non-EU partners, a little more than sixteen percent of the total number of productions. ${ }^{240}$

\section{Member State Standards for National Treatment of Co-Productions}

In general, the complexity of international co-productions can have a chilling effect on investors. ${ }^{241}$ Unfortunately, regulatory initiatives to simplify co-production are almost non-existent. Co-productions with European partners must qualify as "national works" to get national treatment on Member State subsidies, quotas, and taxes, and "European Works" to apply toward the TWFD quota and receive EC subsidies. Widespread discrepancies exist between EU Member States as to standards for "national works" qualification. ${ }^{242}$ A survey of intra-European co-productions found only two cases where EU states agreed on the number of co-productions between their respective countries. ${ }^{243}$

The U.K., Italy, France, Germany, and Norway all have various coproduction treaties effecting "national treatment" of film, but none directly involve the United States. ${ }^{244}$ Some Member States only accord national treatment to co-productions within the context of specific government made treaties, or when there is actual production involvement by their country. ${ }^{245}$ Other Member States regard forms of co-financing, pre-sales, or even the use of post-production facilities as factors qualifying a "national work."246 American producers seeking to avail themselves of EU Member State benefits do not have uniform standards from which to work. Furthermore, even if a co-production qualifies for national treatment, it may still not meet the "European Works" standard.

239. Id.

240. Id. This represents a $3.7 \%$ rise from the 1992 level of European co-productions with non-EU partners. See id.

241. Greg Coote, president of Australia's Village Roadshow Pictures, explains the complexity of one such deal: "We're looking at a picture about Greenpeace, written by a Canadian who lives in Santa Monica. So this Australian-Canadian co-production meets on Montana Avenue [in Santa Monica]." U.S. Pic Makers Seek Ways, Coin to Go Int 'l, supra note 49. Before the production can go ahead, Coote must get French involvement and meet that country's coproduction regulations to get access to French funds and tax incentives. Id.

242. Co-Production in Europe, supra note 238.

243. Id. The number of Portugal/Belguim and U.K./France co-productions was agreed to by both participating nations. Id.

244. See Margaret Moore, supra note 45 (delineating typical threshold criteria and Member State agencies administrating co-production treaties).

245. Co-Production in Europe, supra note 238.

246. Id. 


\section{Member State Standards for EC "European Works"}

Co-productions must meet the TWFD Article 6 definition for "European works" to be considered "European" for TWFD quota purposes and eligible for EC subsidies. Essentially an American co-production may be considered a "European work" if it meets two requirements:

(1)(a) It is "made by one or more producers established in" Member States, ${ }^{247}$ or

(b) It is "supervised and actually controlled by one or more producers established" in Member States; ${ }^{248}$ or

(c) "[T]he contribution of co-producers" from Member States "to the total co-production costs is preponderant and the coproduction is not controlled" by producer(s) established outside Member States; ${ }^{249}$ and

(2) It is "made mainly with authors and workers residing in one or more [Member States]"250 (emphasis added).

This broad definition has left a great deal of room for Member States to develop divergent interpretations. ${ }^{251}$ In France, the leeway in Article 6 has been used to develop a strict regulatory interpretation of "European work" based on a point system. ${ }^{252}$ Other Member States have created informal discretionary interpretations of qualifying "European works," dependent on a case-by-case evaluation. ${ }^{253}$

If a co-production fails to fully meet the amorphous "European work" standard, it will be relegated to the status of a "partially qualified" work under

247. TWFD, supra note 23 , art. $6.2(\mathrm{a})$.

248. Id. art. 6.2(b).

249. Id. art. $6.2(\mathrm{c})$

250. Id. art. 6.1 .

251. See Moebes, supra note 46, at 8 - 9. For example, "established" could relate to a period of time, the size of the operation, the intent of the parties, or some combination thereof. Id. Similar questions arise for the term "residing." Id. "Supervised and actually controlled" could refer to creative control or ultimate monetary control. Id. "Mainly" made by resident workers could mean the preponderant number of people or the preponderance of actual creative input. Id. Finally, it is not clear how much creative input makes one an "author," or what jobs qualify as "worker." Id.

252. Id at 8. See also Decree No. 90-66 of Jan. 17, 1990, Journal Officiel de la Republique Francaise, [J.O.] Jan. 18, 1990 at 757 (codifying France's "European works" legislation).

253. Letter from Manuel Kohnstamm, Representing Time Warner Europe, to Melanie Moen, Director of Legal Affairs, American Film Marketing Association(June 14, 1994) (on file with the IND. INT'L \& COMP. L. REV.). 
Article 6.4. ${ }^{254}$ It counts as a "European Work" only to the pro rata extent that the EU Member State co-producers contributed to the cost of the production. ${ }^{255}$ Thus a ninety-minute film in which the EC partners contributed one-third of the budget will qualify as a thirty-minute "European work" for quota and subsidy purposes.

The Council of Europe's Convention on Cinematographic Co-Production (CCC) was developed to clear the thicket of co-production treaties and regulations existing between the $\mathrm{EC}$ and Member States. ${ }^{256}$ Films qualifying under the CCC regime would be considered both "European works" and "national" productions of the signatory states whose co-producers participated in the production. ${ }^{257}$

The CCC applies only to productions involving three co-producers in three separate signatory states. ${ }^{258}$ Co-producers from outside states may be involved to a limit of thirty percent of total production costs. ${ }^{259}$ The CCC provides that a European film be in a language "culturally suited to the work. "260 Further, the CCC sets up a point system to evaluate co-productions. A film must have fifteen of a total nineteen points to qualify as "European." 261

Although the CCC may represent a move in the direction of clarifying co-production regulations, its limitations on non-EU member investment and trilateral structure make it questionable as a means for American producers to work with Member State producers. A comprehensive regulatory program must be developed that encourages the dominant U.S. audiovisual industry to form production partnerships with creative control vested in the EU partners.

\section{B. How U.S. Companies are Dealing with Co-production Difficulties}

American film industry leaders are looking for innovative ways to enter into cooperative enterprises with their European counterparts. ${ }^{262}$ The seven

254. TWFD, supra note 23, art. 6.4. See also Moebes, supra note 46, at 10 .

255. Id.

256. Council of Europe's European Convention on Cinematographic Co-Production, Oct. 2, 1992, Europ. T.S. No. 147 [hereinafter CCC].

257. Id. As of 1994, the CCC needs to be signed by five more nations to take effect. Id.

258. Moore, supra note 45.

259. CCC, supra note 256 .

260. Id.

261. See Moore, supra note 45. Directors, screenwriters, and lead actors from signatory states each rate three points. Id. "Second lead" actors are worth two points, and "third lead" actors are worth one point. Id. A point is given for the music composer, the editor, the postproduction facility, and the location or studio. Id.

262. Michael Williams, DEJA VU VALENTI VIEW; Pushes Free Market Pix Message in Paris, DAILY VARIETY, Sept. 29, 1994, at 18. 
major Hollywood studios began quietly talking with EU producers about joint ventures in film, television production, and distribution soon after the close of the Uruguay Round. ${ }^{263}$ The EU-U.S. Audiovisual Roundtable, hosted by European Parliament deputies on November 3, 1994, provided a forum for MPAA president Jack Valenti to pledge Hollywood assistance in boosting the European film industry. ${ }^{264}$ Filmmakers and distributors from both sides of the Atlantic participated in the forum. ${ }^{265}$ Roundtable administrator David Reinfeld promised the pending announcement of a broad joint campaign. ${ }^{266}$

American audiovisual industries have begun investing in development of European televisions shows and TV movies directly with European broadcasters. ${ }^{267}$ Inroads to co-production have also come through "format" deals, in which popular programs are franchised to European television producers. ${ }^{268}$ The system has been particularly successful with "local formats" programming that lends itself to regionalization, such as talk shows, game shows, daily/weekly serial dramas, and to a lesser extent sitcoms. ${ }^{269}$

Conversely, Hollywood producers, faced with a lack of original material, have turned to remakes of successful European films. ${ }^{270}$ The trend has positive and negative consequences for European producers. In addition to infusing money from licensing rights for remakes, studios may hire key European

263. Buerkle, supra note 102.

264. Suzanne Perry, Hollywood Set to Help European Filmmakers, ReUTERS NewswIRE, Nov. 3, 1994, available in WESTLAW, INT-NEWS-C Database. This includes cooperation on developing digital dubbing techniques, and a $\$ 40,000$ grant to Media 95 sponsored Media Business School. Id.

265. John Carvel, Europe and Hollywood Close to Peace Deal, GUARDIAN, Nov. 2, 1994, at 16.

266. EU, U.S. Film Producers Agree to Cooperate, REUTERS NEWSWIRE, Nov. 3, 1994, available in WESTLAW, INT-NEWS-C Database.

267. Twentieth-Century Fox recently began co-production on a television game show slated to air in Britain, Spain, Germany, and Scandinavia, investing \$2.5 million in the "science-fiction" set where it will be produced. Hollywood to the Rescue as Culture War Abates, supra note 102. Hearst Enterprises and state-owned German television broadcaster ZDF announced a joint fund to develop TV movies and mini-series for global distribution. Hearst and ZDF to Develop TV Movies and Documentaries, EUROMARKETING, Nov. 3, 1994, available in WESTLAW, INT-NEWS-C Database.

268. Robert Marich, MIPCOM Heat: The Format Deal; Foreign Broadcasters See Wisdom in Growing There Own -- With Help, HollywOOD REPORTER, Oct. 14 1994, at 5.

269. Id. These types of programs are high volume, filling a great deal of airtime for a relatively low price. $I d$. The system also provides the unique advantage of allowing local producers to develop and incorporate regional sponsorships. Id.

270. Recent remakes include "La Femme Nikita," "Breathless," and "Three Fugitives." Vernon Scott, supra note 156. 
personnel from the original. ${ }^{271}$ However, remakes do not increase U.S. distribution of these original European works. In fact, they may actually have a negative impact. ${ }^{272}$ Hollywood producers buy the U.S. rights to the best European productions, and shelve the original to concentrate on the remake. ${ }^{273}$ There is no financial impetus for major studios to nurture a dubbed or subtitled film through a limited release when a big-budget remake can garner higher box office receipts in a single day. ${ }^{274}$

Disney Studios has taken a lead in remedying the situation by creating a subsidiary to market French films in the U.S. and co-produce with France. ${ }^{275}$ Disney is at the forefront of European remakes, having previously sired bigbudget reproductions, including "Three Men and a Baby," "Three Fugitives," "Paradise," and "My Father the Hero." The subsidiary, launched in 1994, plans to distribute at least three new French pictures a year, and has set aside $\$ 3$ million to $\$ 4$ million for redubbing. ${ }^{276}$

\section{CONCLUSION}

The American initiative to enter into cooperative ventures with European producers, notwithstanding the regressive EU co-production regulatory scheme, is indicative that the false economies generated by legislated protectionism cannot be sustained against the pressures of the free market. If the recent fall of communism around the world has taught any lesson, it is that government subsidies and regulation cannot indefinitely withstand economic forces. No trade barrier can prevent people from going to see a good film, and no subsidy can persuade them to see a bad one. ${ }^{27}$

The current legislative course contemplated by the European Commission will work to the long-term detriment of the audiovisual sector. Taken to the extreme, the protectionist stance could render Europe a non-entity in the burgeoning information age. The underdevelopment of the European audiovisual market represents a tremendous economic loss to both Europe and the U.S.

271. Josh Young, Hollywood's Love of Remakes Means Rejection of French Originals, N.Y. TIMES, Oct. 30, 1994, at 1C.

272. Id.

273. Id.

274. Id.

275. Pia Farrell, Miramax Cook Up New Unit for French Fare; Goal: 'Greater Exposure on American Screens', HOLLYWOOD REPORTER, Oct. 10, 1994.

276. Id. Miramax has also promised investments of $\$ 20$ to $\$ 30$ million in future French co-productions. Id. The cash investment is relatively small by Hollywood standards. French filmmakers view the move as an appeasement for continuing efforts to infiltrate the French entertainment market. Id.

277. Griffiths, supra note 18. 
It is therefore in the interest of all parties to work toward creating a healthy, thriving European audiovisual industry.

Europe must resist the cultural bureaucrats who value self-preservation over the good of the European Community. Rather than pursuing novel regulatory schemes, the EC should be seeking ways to deregulate in a controlled fashion, so as to best benefit from the resulting economic shift. By simplifying and clarifying co-production regulations, the EC could generate a cash influx on its own terms, retaining cultural and creative control. The two-step program outlined here offers an efficient method to rehabilitate the European audiovisual industry.

Craig R. Karpe*

- J.D. Candidate, May 1995, Indiana University School of Law-Indianapolis; B.A., Indiana University. 
